\title{
Myelopathy associated with cervical epidural spinal metastasis of follicular-compact thyroid carcinoma in two dogs
}

\author{
Mielopatia associada à metástase epidural cervical de carcinoma folicular-compacto de \\ tireoide em dois cães
}

\begin{abstract}
Camila Tochetto ${ }^{I}$ Fábio Brum Rosa ${ }^{\mathrm{I}}$ Rosmarini Passos dos Santos ${ }^{\mathrm{I}}$ Alexandre Mazzanti ${ }^{\mathrm{II}}$ Rafael Almeida Fighera ${ }^{\mathrm{III}}$ Glaucia Denise Kommers ${ }^{\mathrm{II}}{ }^{*}$
\end{abstract}

\section{- NOTE -}

ABSTRACT

This case report describes the clinical, histopathological and immunohistochemical findings in two dogs with myelopathy associated with metastasis of follicular-compact thyroid carcinoma. Microscopically, both primary neoplasms were characterized by polygonal cells arranged in follicles (occasionally filled with eosinophilic colloid-like material) or in sheets. The neoplastic cells had a moderately eosinophilic cytoplasm and there was moderate anisokaryosis and anisocytosis. Additionally, the neoplastic cells were positive for thyroglobulin on immunohistochemistry, confirming the follicular origin of both tumors. This is a very uncommon presentation of this pathological condition.

Key words: immunohistochemistry, oncology, thyroid tumor, neurooncology.

RESUMO

Este relato de caso descreve os achados clínicos, histopatológicos e imuno-histoquímicos em dois cães com mielopatia associada à metástase de carcinoma de tireoide. Microscopicamente, ambos os neoplasmas primários eram caracterizados por células poligonais arranjadas em folículos (ocasionalmente preenchidos por material eosinofilico semelhante a coloide) ou em folhetos. As células neoplásicas tinham moderado citoplasma eosinofilico e moderada anisocitose e anisocariose. Adicionalmente, as células neoplásicas foram positivas para tireoglobulina, confirmando a origem folicular dos tumores em ambos os cães. Essa é uma apresentação incomum dessa condição patológica.

Palavras-chave: imuno-histoquimica, oncologia, tumor de tireoide, neurooncologia.
Thyroid tumors occur in man and animals. In dogs, thyroid carcinomas are more frequent and often have both follicular and compact cellular growth pattern. The most common metastatic site is the lung; the retropharyngeal and caudal cervical lymph nodes are less frequently affected (CAPEN, 2002). The aim of this report is to describe two cases of thyroid carcinoma with infrequent metastatic pattern and secondary mielopathy.

Case 1 (2012), an 11-year-old intact male Boxer, showed a mass in the right lateral neck, with cervical stiffness, hyperesthesia and tetraparesis. Myelography revealed an area of spinal cord compression in the cervical spine (C2). The dog died and was submitted for necropsy and histopathological evaluation.

At necropsy, there was a slightly infiltrative, multilobulated and light brown mass $10.0 \times 6.0 \mathrm{~cm}$ between the neck muscles on the right side, which corresponded to the left lobe of the thyroid gland that was completely replaced by the neoplasm. The mass was $2.5 \mathrm{~cm}$ wide at the cranial portion and $3.5 \mathrm{~cm}$ wide at the caudal portion. On the cut surface, the mass was soft and white, with some red spots (Figure 1A). The right lobe of the thyroid was normal. In the right ventral vertebral canal, between $\mathrm{C} 1-\mathrm{C} 2$, there was an epidural, white to grey, non-encapsulated, well-demarcated and multilobulated mass that was

\footnotetext{
IPrograma de Pós-graduação em Medicina Veterinária, Universidade Federal de Santa Maria (UFSM), Santa Maria, RS, Brasil.

"Laboratório de Cirurgia Experimental, Departamento de Clínica de Pequenos Animais, UFSM, Santa Maria, RS, Brasil.

IIILaboratório de Patologia Veterinária, Departamento de Patologia, Hospital Veterinário Universitário, UFSM, Av. Roraima 1000, Camobi, 97105-900, Santa Maria, RS, Brasil. E-mail: glaukommers@yahoo.com. *Corresponding author. Received 08.21.14 Approved 12.22.14 Returned by the author 03.27.15 CR-2014-1239.R2
} 


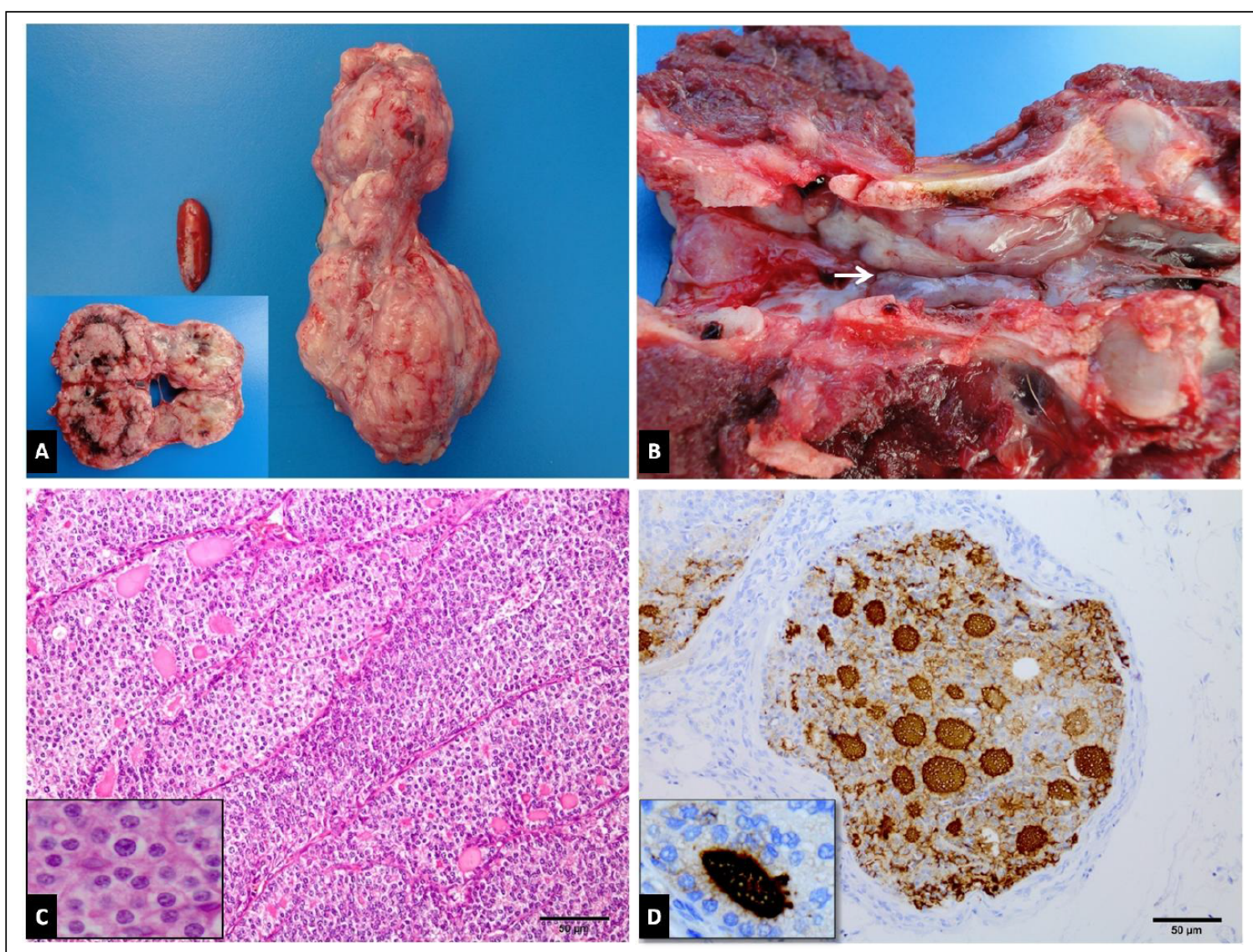

Figure 1 - Follicular-compact thyroid carcinoma. Case 1. The right lobe of the thyroid is completely replaced by a tumor mass. Inset: on the cut surface, the mass is soft and white with some red spots. The left lobe was normal. (A). Metastasis of follicularcompact thyroid carcinoma. Case 1. Between $\mathrm{C} 1-\mathrm{C} 2$, there is an epidural, well-demarcated and multilobulated mass (arrow) causing spinal cord compression (spinal cord has been removed). (B). Histology of the thyroid tumor. Case 2. A follicular-compact thyroid carcinoma with neoplastic cells organized in follicles or in sheets. HE. Bar, 50 $\mu \mathrm{m}$. Inset: the neoplastic cells had a moderately eosinophilic cytoplasm. The nuclei were round with finely granular chromatin. There was moderate anisokaryosis and anisocytosis.(C). Immunohistochemical characterization of the follicular-compact thyroid carcinoma. Case 2. The neoplastic cells are strongly positive for thyroglobulin. IHC. Bar, 50 $\mu$ m. Inset: the apical cytoplasm is stained and the colloid is more strongly stained. (D).

$4.0 \times 0.6 \times 0.8 \mathrm{~cm}$ (Figure 1B) and compressed the spinal cord, (which caused the secondary mielopathy clinically described). A complete necropsy was performed and no other metastases were detected.

Microscopically, the cervical mass was non-encapsulated and composed of polygonal cells arranged in follicles or in sheets, separated by thin fibrovascular bundles. The neoplastic follicles were of different sizes, were arranged in 1-2 layers of cells and were occasionally filled with eosinophilic colloidlike material. The neoplastic cells had a moderately eosinophilic cytoplasm. The nuclei were round with finely granular chromatin and had 1-3 nucleoli. There was moderate anisokaryosis and anisocytosis. There was an average of 2-3 mitotic figures per high power field (400x). The arteries and lymphatic vessels contained emboli of the tumor cells. There were necrotic areas admixed with proteinaceous fluid, fibrin, cholesterol clefts and hemorrhage randomly in the stroma. There was no remaining thyroid parenchyma observed. According to the World Health Organization (WHO) system (KIUPEL et al., 2008), the neoplasm was classified as a follicular-compact thyroid carcinoma. The cervical epidural mass was diagnosed as metastasis. The spinal cord (C1-C2) had Wallerian degeneration with axonal spheroids in the ventral funiculus.

Case 2 (2008), a 12-year-old intact female Dachshund, presented with swelling on the left side of the neck, severe dyspnea and paralysis. A myelography showed contrast displacement at C1. Hemilaminectomy was performed between C2-

Ciência Rural, v.45, n.8, ago, 2015. 
C3, and mass fragments, which occupied part of the spinal canal, were removed and submitted for histopathological evaluation. The dog was submitted to euthanasia due to the poor prognosis and was submitted for necropsy and histopathological evaluation.

Grossly, the left lateral-ventral region of the neck showed a red amorphous mass of $8.0 \times 5.0 \times 3.5 \mathrm{~cm}$ infiltrating the regional skeletal muscles. On the cut surface, the mass was soft. In the proximal esophagus there were some white, firm nodules $3-5 \mathrm{~mm}$ in the tunica adventitia. Within the cranial vena cava, at the mediastinum region, a $5 \times 2 \mathrm{~cm}$ thrombus was found. All of the lung lobes had white and firm nodules ranging from 0.3 to $1.5 \mathrm{~cm}$. In this case, as well as in the case 1, the corresponding vertebral bodies (where the epidural metastases were found) were not affected.

Histologically, the cervical mass was characterised by a proliferation of neoplastic epithelial cells, which were similar to those observed in case 1 (Figure 1C). Groups of tumor cells were seen within the small arteries and lymphatic vessels. The neoplasm was classified as a follicular-compact thyroid carcinoma. Large aggregates of neoplastic cells invaded the adjacent skeletal muscles of the neck. The lung masses, the small nodules observed in the tunica adventitia of the esophagus and the epidural spinal mass were histologically characterized as metastases of the thyroid follicular-compact carcinoma. Wallerian degeneration was present in all of the funiculi of the spinal cord (C1-C2).

In both cases, sections $(4 \mu \mathrm{m})$ of the primary tumor and fragments of the epidural spinal metastases were submitted for immunohistochemistry (IHC) with primary antibodies specific for thyroglobulin (mouse monoclonal, clone DAK-tg6; DAKO) and calcitonin (rabbit polyclonal; DAKO). The slides were dewaxed and rehydrated. The antigens were retrieved using a citrate buffer ( $\mathrm{pH}$ 6.1) for calcitonin and Tris-EDTA ( $\mathrm{pH} 9.0$ ) for thyroglobulin for $20 \mathrm{~min}$ at $97^{\circ} \mathrm{C}$. The endogenous peroxidase was blocked with Envision Flex peroxidase block (DAKO) for $5 \mathrm{~min}$. The primary antibodies were diluted to $1: 1,000$ (for thyroglobulin) and 1:32,000 (for calcitonin), and an overnight incubation was performed. On the following day, the slides were incubated in a wash solution for $5 \mathrm{~min}$ and incubated with a polymer (Envision Flex/HRP; DAKO) for $20 \mathrm{~min}$. The peroxidase reaction was developed for 10min with 3, 3'-diaminobenzidine (DAB). The slides were washed for $5 \mathrm{~min}$ and counterstained with Mayer's haematoxylin. The pattern of staining for thyroglobulin in the primary tumor was cytoplasmic. The apical cytoplasm often stained more strongly (Figure 1D-inset). Immunoreactivity was limited almost exclusively to the areas of follicular differentiation, mainly when colloid was present (Figure 1D). The fragments of the epidural spinal metastases were positive in one case (case 1) and were characterised by random weak cytoplasmic immunostaining. In both cases, the tumor cells were negative for calcitonin, excluding the differential diagnosis of $\mathrm{C}$ cell carcinoma.

Boxers are reported to develop thyroid carcinoma more frequently. The higher risk among Boxers is thought to be partly due to the anomalous follicular patterns commonly seen in their thyroid gland. Dachshunds are not listed as a breed predisposed to developing thyroid carcinoma (CAPEN, 2002).

Unilateral involvement with thyroid carcinomas, as was observed in both dogs reported here, is approximately twice as frequent in dogs as the involvement of both lobes (CAPEN, 2002). Carcinomas are generally poorly encapsulated and invade locally into the wall of the trachea, cervical muscles, esophagus, larynx, nerves and vessels (CAPEN, 2007). In case 2, the mass was infiltrative and invaded the cervical muscles. In the same case, the esophageal tunica adventitia was invaded, and there was a neoplastic thrombus in the cranial vena cava. The lungs and the regional lymph nodes are the most common metastatic sites (CAPEN, 2002). Early invasion into the branches of the cranial and caudal thyroid veins with the formation of tumor cell thrombi leads to multiple pulmonary metastases, often before the involvement of the retropharyngeal and caudal cervical lymph nodes (CAPEN, 2007), as noted in case 2 . Although the tumor cells were observed inside the lymphatic vessels in both cases, the lymph nodes were not affected in either case.

In general, spinal metastases of different tumors in humans typically affect the thoracic $(60$ $80 \%)$, lumbar $(15-30 \%)$ and cervical spine $(<10 \%)$ (SCIUBBA et al., 2010). Both of the dogs of this report had spinal metastases located between the cervical vertebrae (C1-C3). For thyroid tumors, the route of dissemination from the thyroid to the spine is through the blood vessels, with venous spread or direct arterial embolization of the tumor cells (RAMADAN et al., 2012). Some authors report that in animals, arterial embolization is the most common and important route of spinal metastases (ARGUELLO et al., 1990). The vertebral body $(85 \%)$ is the most common site of initial involvement, followed by the paravertebral space (10-15\%) and the epidural space 
$(<5 \%)$ (HAREL \& ANGELOV, 2010). It is believed that bone involvement can be explained based on the bone features that render the bone fertile for tumor growth, predisposing it to spinal metastases. The vascularity of the vertebral bodies provides access for tumor cells, and an absence of valves in the vertebral veins cause blood stasis. It was described metastatic thyroid carcinoma in the cervical spine with extradural location (WRIGHT, 1985; BENTLEY et al., 1990) and bone invasion in dogs (WRIGHT, 1985). On rare occasions, the metastatic tissue invades the vertebral canal without causing damage to the vertebral bodies (RAMADAN et al., 2012), as was observed in these two cases. In both cases, the metastases were found in the epidural space of the cervical spine, two less common locations for spine metastases in general, and caused spinal cord compression. Other metastatic sites of thyroid carcinomas in animals include the adrenal glands, brain, kidneys, heart and liver (MOONEY, 1985).

The IHC characterization of the thyroid cells was performed with antibodies against thyroglobulin (specific for thyroid follicular cells) and calcitonin (specific for thyroid C-cells [or parafollicular cells]) (RAMOS-VARA et al., 2002; CIAPUTA et al., 2014). In this report, the stain was positive only for thyroglobulin, confirming the diagnosis of thyroid follicular cell carcinoma in both primary tumors. The IHC pattern of staining described here was similar to those previously described for follicular-compact thyroid carcinomas in dogs (RAMOS-VARA et al., 2002). The epidural metastases staining were weak in one case and negative in the other case. These results can be explained by the fact that the reported sensitivity of thyroglobulin to detect primary thyroid carcinomas is high $(90-100 \%)$, but only $50 \%$ of metastases are detected with this marker (MOORE et al., 1984). The best hypothesis for this result is a different grade of differentiation between the primary and the metastatic tumor cells (DABBS, 2006).

According to a review study (BARBER, 2007), in general the presence of thyroid tumor metastasis has not been correlated to clinical signs and only $20 \%$ of the cases did not have recognized lung metastasis, and the regional lymph nodes were commonly affected in most studies; metastasis to the lungs was seen only in case 2 and neither of the cases reported here had lymph node involvement. The authors conclude that cervical epidural spinal metastasis of thyroid carcinoma is a very uncommon condition. Probably, the route of dissemination from the thyroid to the spine was arterial embolization of the tumor cells.

\section{ACKNOWLEDGEMENTS}

To Conselho Nacional de Desenvolvimento Científico e Tecnológico (CNPq) for productivity scholarship of Glaucia D. Kommers and doctoral scholarship of Camila Tochetto (141398/2012-4).

\section{REFERENCES}

ARGUELLO, F. et al. Pathogenesis of vertebral metastases and epidural spinal cord compression. Cancer, v.65, p.98-106, 1990. Available from: <http://www.ncbi.nlm.nih.gov/pubmed/2293874>. Accessed: sept. 20, 2013.

BARBER, L.G. Thyroid tumors in dogs and cats. Veterinary Clinics of North America: Small Animal Practice, v.37, p.755-773, 2007. Available from: <http://www.ncbi.nlm.nih.gov/ pubmed/17619010>. Accessed: sept. 20, 2013. doi: 10.1016/j. cvsm.2007.03.008.

BENTLEY, J.F. et al. Metastatic thyroid solid-follicular carcinoma in the cervical portion of the spine of a dog. Journal of the American Veterinary Medical Association, v.197, p.14981500, 1990. Available from: <http://www.ncbi.nlm.nih.gov/ pubmed/2272884>. Accessed: sept. 20, 2013.

CAPEN, C.C. Tumors of the endocrine gland. In: MEUTEN, D.J. Tumors in domestic animals. 4.ed. Ames, Iowa: Iowa State, 2002. Cap.13, p.607-696.

CAPEN, C.C. Endocrine glands. In: MAXIE, G.M. Jubb, Kennedy, and Palmer's, pathology of domestic animais. 6.ed. Philadelphia, Pennsylvania: Sauders Elsevier, 2007. V.3, p.325-428.

CIAPUTA, R. et al. Morphological and immunohistological characteristics of follicular-compact thyroid carcinoma in dog. Folia Histochemica et Cytobiologica, v.52, p.157-161, 2014. Available from: <http://www.ncbi.nlm.nih.gov/pubmed/25007184>. Accessed: sept. 20, 2013. doi: 10.5603/FHC.2014.0009.

DABBS, D.J. Immunohistology of endocine tumors. In: Diagnostic immunohistochemistry. 2.ed. Philadelphia, Pennsylvania: Elsevier, 2006. p. 261-300.

HAREL, R.; ANGELOV, L. Spine metastases: current treatments and future directions. European Journal of Cancer, v.46, p.2696-2707, 2010. Available from: <http://www.ncbi.nlm.nih. gov/pubmed/20627705> . Accessed: sept. 20, 2013. doi: 10.1016/j. ejca.2010.04.025.

KIUPEL, M. et al. Histological classification of tumors of the endocrine system of domestic animals. Washington, DC: Armed Forces Institute of Pathology, 2008. 192p.

MOONEY, C.T. Hyperthyroidism. In: ETTINGER, S.J.; FELDMAN E.C. Textbook of Veterinary Internal Medicine: diseases of the dog and cat. 6.ed. Saint Louis, Missouri: Elsevier Saunders, 1985. p.1544-1560.

MOORE, F.M. et al. Thyroglobulin and calcitonin immunoreactivity in canine thyroid neoplasms. Veterinary Pathology, v.21, p.168-173, 1984. Available from: <http://www. ncbi.nlm.nih.gov/pubmed/6375099>. Accessed: sept. 16, 2013. doi: $10.1177 / 030098588402100206$. 
RAMADAN, S. et al. Spinal metastasis in thyroid cancer. Head and Neck Oncology, v.4, p.1-19, 2012. Available from: $<\mathrm{http}: / /$ www.ncbi.nlm.nih.gov/pmc/articles/PMC3466148/>. Accessed: sept. 16, 2013. doi: 10.1186/1758-3284-4-39.

RAMOS-VARA, J.A. et al. Immunohistochemical detection of thyroid transcription factor-1, thyroglobulin, and calcitonin in canine normal, hyperplastic, and neoplastic thyroid gland. Veterinary Pathology, v.39, p.480-487, 2002. Available from: <http://www. ncbi.nlm.nih.gov/pubmed/12126151>. Accessed: sept. 16, 2013. doi: $10.1354 /$ vp.39-4-480
SCIUBBA, D.M. et al. Diagnosis and management of metastatic spine disease: a review. Journal of Neurosurgery Spine, v.13, p.94-108, 2010. Available from: <http://www.ncbi.nlm. nih.gov/pubmed/20594024>. Accessed: Sept. 16, 2013. doi: 10.3171/2010.3.SPINE09202.

WRIGHT, J.A. The pathological features associated with spinal tumors in 29 dogs. Journal of Comparative Pathology, v.95, p.549-557, 1985. Available from: <http://www.sciencedirect.com/ science/article/pii/0021997585900246>. Accessed: sept. 16, 2013. doi: 10.1016/0021-9975(85)90024-6. 